\title{
STUDI KOMPARASI MODEL KELEMBAGAAN PENGELOLAAN AIR BERSIH BERBASIS PARTISIPASI MASYARAKAT DI KAWASAN KAKI GUNUNG MANGLAYANG
}

\author{
Ramadhan Pancasilawan,dan Ahmad Buchari \\ E-mail : ramadhanpancasilawan@gmail.com
}

\begin{abstract}
Abstrak Penelitian ini akan memfokuskan pada identifikasi kelembagaan masyarakat dalam pengelolaan air di kawasan kaki Gunung Manglayang. Latar belakang penelitian ini bahwa sudah banyak sumber mata air yang dikelola dan dimanfaatkan oleh pemerintah daerah/lokal, kelompok masyarakat baik dalam pengelolaan sumber mata air atau kelompok masyarakat yang memanfaatkan air tersebut, kemudian swasta yang memiliki kepentingan dalam pengelolaan air tersebut. Penelitian ini akan menggunakan pendekatan kualitatif, dengan mengambil informan dari stakeholder yang terlibat dari pengelolaan air yang bersumber dari Kaki Gunung Manglayang hingga pemanfaatannya yang berada di daerah Ujung Berung Kota Bandung. Maka dari itu dari penelitian ini diharapkan akan teridentifikasi dan tersusun model kelembagaan masyarakat yang berbasiskan partisipasi dalam pengelolaan air. Secara keseluruhan model yang ada di daerah Manglayang mengenai pengelolaan air bersih cukup beragam. Hal ini dikarenakan penyebab pembentukan kelompok serta partisipasi masyarakat yang berbeda-beda. Jika melihat model di Desa Melatiwangi, kelompok terbentuk diprakarsai oleh pemerintah kabupaten dengan menggunakan modal yang cukup besar. Sedangkan bentuk lainnya kelompok terbentuk dengan intensitas kecil dan tidak besar hingga banyak melibatkan masyarakat.
\end{abstract}

Kata Kunci: Model Kelembagaan, Partisipasi, Pengelolaan Air

\section{INSTITUTIONAL MODEL OF CLEAN WATER MANAGEMENT BASED ON PUBLIC PARTICIPATION IN THE AREA OF THE MANGLAYANG MOUNTAIN}

\begin{abstract}
Abstrack This research will focus on the identification of institutional communities in water management at the Mount Manglayang area. Base on a background of this research that has many spring that are managed and utilized by the community. The Act of Water Resources required joint efforts in participation of each stakeholder in the water management. These stakeholders include local/regional governments, community groups that involved in spring management and the society that take advantages of spring, even private that have an interest in clean water management. This study will use a qualitative approach, by taking the informant from stakeholders that involved from water management were sourced from the Mount of Manglayang and its utilization in the area of The Ujung Berung Bandung. Thus from this study are expected to be identified and arranged institutional models of community-based participation in clean water management. In overall models that exist in the area of Manglayang on the management of clean water are quite diverse. This is because the causes of the formation of the group as well as the participation of different communities. A model in the village of Melatiwangi, the Group initiated by District Government formed by using a large enough capital. While other forms of groups formed by small and not great intensity to a lot of community involve.
\end{abstract}

Key word: Institutional Model, Prticipation, clean water/spring management

\section{PENDAHULUAN}

Air merupakan sumber alam yang sangat diperlukan oleh manusia. Namun justru banyak terjadi eksploitasi besar-besaran dalam penggunaannya. Bahksn di Indonesia telah diamanatkan dalam Undang-Undang Dasar 1945, bahwa air dimanfaatkan untuk kemakmuan dan kesejahteraan masyarakat. Oleh karena begitu banyak upaya yang dilakukan untuk mengantisipasi permasalahan yang berkaitan dengan air, seperti kekeringan, atau bahkan kebanjiran.

Permasalahan yang terjadi di masyarakat dalam pengelolaan air bersih terutama di wilayah perkotaan justru semakin meluas, sebab air bersih yang dikelola justru menjadi kepemilikan pribadi. Kemudian pengelolaan dilakukan hanya untuk kepentingan ekonomi saja. Walaupun pemerintah sudah berupaya untuk membangun fasilitas air bersih untuk kepen tingan masyarakat tetapi justru tidak dapat berjalan dengan baik.

Hingga permasalahan pengelolaan air tidak hanya terkait pada satu pihak saja, misalkan hanya pemerintah daerah saja, tetapi juga menjadi tanggung jawab bersama bagi stakeholder yang terlibat di dalamnya.
Penggunaan air bersih di Wilayah Bandung cukup pesat, dengan bertumbuhnya industri dan perkembangan hunian. Hal ini menyebabkan sumber air bersih berkurang. Bahkan pada musim kemarau, beberapa wilayah di Bandung mengalami kekeringan. Hal ini memberikan keuntungan untuk sebagian kecil masyarakat, yaitu bagi yang memliki sumber air bersih akan dijual ke masyarakat yang membutuhkannya.

Sumber air bersih ini biasanya terletak di sekitar wilayah Gunung Manglayang masuk wilayah Kabupaten Bandung, sedangkan penikmat air sebagian besar adalah penduduk Kota Bandung terutama di sekitar utara Jalan A.H. Nasution (Terminal Cicaheum sampai Cileunyi). Kondisi ini terus terjadi sebab dari daerah resapan air di sekitar Gunung Manglayang yang sudah tidak baik sebab banyak lahan hutan yang beralih fungsi menjadi lahan pertanian sayur-sayuran. Hingga daerah sekitar Jalan A.H. Nasution tidak memiliki sumber air bersih.

Maka dari itu sudah ada model pengelolaan air yang bersifat lokal untuk memanfaatkan sumber mata air bersih yang dimanfaatkan oleh masyarakat. Model pengelolaan ini biasanya hanya melingkupi 

Gunung Manglayang (Ramadhan Pancasilawan,dan Ahmad Buchari)

satu komplek atau perumahan atau bahkan lebih kecil, bisa hanya beberapa KK untuk mengelola satu sumber mata air saja. Hal ini memperlihatkan bahwa masih cukup banyak sumber mata air yang airnya terus mengalir dan dapat dimanfaatkan oleh masyarakat. Maka penelitian ini akan melihat partisipasi masyarakat yang terlembagakan dalam pengelolaan sumber mata air di Wilayah Gunung Manglayang.

Tujuan penelitian ini adalah akan terpetakan kelembagaan masyarakat dalam pengelolaan sumber mata air, yang didalamnya akan terlihat partisipasi yang dilakukan oleh masyarakat. Kemudian akan teridentifikasi kelembagaan masayrakat yang berbasis partisipasi masyarakat yang dapat dikembagkan menjadi model dalam pengelolaa sumber mata air di Wilayah Kaki Gunung Manglayang

Dalam penelitian ini akan melihat kelembagaan yang terbentuk berdasarkan partisipasi masyrakat. Model kelembagaan ini akan melibatkan banyak stakeholder untuk mencapai tujuan bersama, dalam penelitian ini adalah dalam pengelolaan air di kawasan kaki Gunung Manglayang.

Dalam buku Community Development As A Process oleh editor Lee J. Cary menyatakan Model umum dari dimensi interaksi antar masyarakat dalam proses pembangunan masyarakat. Terdiri dari beberapa tahap, yaitu;

1. Tahap 1. (Sumber Daya Organisasi)

2. Tahap II (keterlibatan sumber daya sistem dengan satuan komunitas)

3. Tahap III (mengaktifkan sistem berorientasi pada tujuan setempat)

4. Tahap IV (pengoperasian sistem lokal)

\section{METODE}

Metode yang digunakan dalam penelitian ini adalah metode kualitatif. Dalam penentuan informan, peneliti menjadikan individu/kelompok masyarakat, tokoh masyarakat, pemerintah lokal/daerah dan bahkan pihak swasta yang terlibat langsung dalam pengelolaan air bersih di Cilengkrang dan Giri Mekar sebagai informan, diantaranya Kelompok masyarakat pengelola air dan didalamnya juga ada sebagai informan dari tokoh masyarakat dan pemerintah lokal yaitu dari aparat desa.

Analisis data dilakukan dengan melalui beberapa tahapan, yakni reduksi data, pengkategorian data, penguraian data, penganalisisan data. Reduksi data dilakukan dengan cara mengenyampingkan data yang tidak memiliki hubungan dengan kajian yang akan diteliti. Pengkategorisasian, penguraian, dan penganalisaan data dilakukan terhadap data yang diperoleh dari informan. Pengkategorian data dilakukan dengan cara menggolongkan berbagai data yang sejenis dalam satu kategori, kemudian dilakukan penguraian atau penjelasan dari berbagai data tersebut untuk kemudian dilakukan dengan melakukan penganalisaan data.

\section{HASL DAN PEMBAHASAN}

Lembaga Pengelolaan air yang dikembangkan di Desa Giri Mekar dan Melatiwangi Kecamata Cilengkrang dilakukan melalui partisipasi masyarakat. Proses partisipasi masyakarat dalam pengelolaan sumber mata air tersebut merupakan sebuah dimensi interaksi yang diungkapkan dalam buku Community Development As A Process oleh editor Lee J. Cray menyatakan Model umum dari dimensi interaksi antar masyarakat dalam proses pembangunan masyarakat, dimensi tersebut terdiri dari beberapa tahap. Dari beberapa tahapan tersebut akan dikerucutkan lagi menjadi tahapan yang telah dilakukan masyarakat sepetempat. Selanjutnya akan penulis jelaskan masingmasing tahapan tersebut

\section{Tahap 1. (Sumber Daya Organisasi)}

Tahapan pertama dalam interaksi antar masyarakat dalam proses pembangunan masyarakat adalah sumber daya organisasi. Proses pembangunan masyarakat merupakan sebuah hal yang berkelanjutan. Dalam kasus ini pembangunan masyarakat menjadi cikal bakal terbentuknya kelembagaan pengelolaan air di Desa Giri Mekar dan Desa Melatiwangi Kecamatan Cilengkrang Kabupaten Bandung. Dimulai dari negosiasi untuk memperoleh dukungan yang biasanya berasal dari pribadi yang mempunyai inisiatif lebih untuk mengajak masyarakat lain untuk melakukan hal yang serupa, selanjutnya membangun system pendukung yang berkelanjutan hingga menjelaskan maksud dan tujuan kegiatan. Hal ini diharapkan menjadi permulaan dari proses pembangunan masyarakat.

Kemudian untuk melihat partisipasi yang terjadi pada tahapan pertama ini adalah bahwa dari dimensi Actors (aktor). Berdasarkan hasil kajian terlhat bahwa actor yang terlibat adalah masyarakat lokal yang memiliki kepedulian dalam pengelolaan air bersih. Untuk di desa Melatiwangi, pengelolaan air bersih terjadi ketika terjadinya kejadian luar biasa, yaitu banyaknya masyarakat di Melatiwangi yang terkena diare yang disebabkan oleh sumber air yang tidak sehat, banyak masyarakat yang mengambil air dari sungai. Maka dari itu jika melihat awal mulanya maka di Desa Melatiwangi actor yang terlibat lebih dominan dari pemerintah yang kemudian di kelola oleh masyarakat lokal.

Sedangkan untuk Desa Girimekar actor yang terlibat lebih banyak dari masyarakat lokal yang memiliki sumber air bersih dan juga masyarakat lokal ssetempat yang bahu-membahu dalam membangun pipa untuk menyalurkan air bersih ke rumah-rumah. Namun proses pipanisasi ini juga berdasarkan hasil kolektif dana yang di bebankan kepada pemilik rumah yang menginginkan air bersih dari sumber air ini.

PadadimensiKnowledge(pengetahuan). Mengenai pengetahuan stakeholder yang terlibat dalam proses tahap pertama ini ternyata pengetahuan masyarakat terutama di Desa Melatiwangi tidak terlalu banyak memahami mengenai pemanfaatan sumber air, maka dari itu terjadi kejadian luar biasa yaitu terjangkitnya 
Diare massal karena masyarakatnya memanfaatkan air dari sungai yang tidak bersih. Maka dari itu dari sgi pengetahuan masyrakat Melatiwangi masih kurang paham mengenai pembentukan kelompok dalam pemanfaatan air bersih. Setelah adanya intervensi bantuan dana dari pemerintah kabupaten Bandung, baru adanya pembentukan kelompok yang melibatkan masyarakat untuk pengelolaan air bersih tersebut.

Kemudian untuk Desa Girimekar kondisi pemahaman masyarakat yang mengelola air bersih sudah baik sebab adanya kesadaran dari masyarakat yang menginginkan pemanfaatan air bersih dari sumber mata air yang dimiliki oelh warga tersebut. Pembentukan kelompok terjadi secra informal dengan pengelolaan air bersih berdasarkan partisipasi yang lingkupnya kecil. Sebab kelompok dibutuhkan untuk memelihara dalam pengelolaan air bersih seperti pipa saluran air, proses iuran, atau dalam upaya memperluas masyarakat yang memanfaatkan mata air tersebut.

Sedangkan kondisi situasi pada saat tahap pertama cukup berbeda, jika Girimekar lebih berdasarkan situasi informasl tanpa ada campur tangan dari pemerintah, masyarakat (terutama pemilik air) membuka bagi masyarakat untuk memanfaatkan sumber air yang ada dengan membayar iuran yang bertujuan untuk pemeliharaan dan pembelian instalasi air bersih. Sedangkan Melatiwangi kondisi awal situasinya lebih terjadi karena adanya pembentukan dari intervensi pemeirntah yang berupaya menangani permasalahan yang terjadi di desa tersebut. Kejadian Luar Biasa (KLB) penyakit Diare yang dialami warga Melatiwangi yang cukup banyak terjangkit, menyebabkan perlu adanya campur tangan pemerintah dalam pemanfaatan air bersih.

\section{Tahap II (Keterlibatan Sumber Daya Sitem dan Satuan Komunitas)}

a. Bekerja lepas dari struktur tanpa adanya sebuah struktur birokrasi

Untuk di Desa Giri Mekar Pengelolaan yang dilakukan oleh Pa Amas dan beberapa orang lain dalam masyarakat sendiri adalah pengelolaan tanpa struktur yang baku dan tidak ada birokrasi sama sekali. Hal ini bisa terjadi karena pengelolaan air yang dilakukan di Desa Giri Mekar tidak berbentuk $\mathrm{CV}$ dan tidak pula memiliki SK atau aturan baku yang ditetapkan oleh pemerintah.

Sedangkan untuk Desa Melatiwangi karena sudah dalam bentuk BUM Desa, maka pengelolaannya dapat dilakukan untuk mencari pendapatan bagi desa. Namun dalam prosesnya tetap pemeliharaan yang lebih diutamakan, oleh karena itu pungutan biaya tidak besar hanya pada perumahan/komplek saja yang dikenakan biaya lebih besar daripada warga Melatiwangi sendiri.

Pengelolaan BUM Desa diakukan berdasarkan paritisipasi masayrakat yang difasilitasi oleh Pemerintah Desa dan Kabupaten bandung dengan memberikan sodoran bantuan dana untuk membentuk BUM Desa ini. b. Membuat kepekaan dan kebutuhan untuk mengembangkan komunitas masyarakat

Kasus di Desa Giri Meka cukup berbeda dengan Desa Melatiwangi, untuk di Desa Girimekar, berawal dari tidak adanya kemampuan dari pemerintah sendiri untuk membuat system pengelolaan yang baik, maka hal ini mendorong $\mathrm{Pa}$ Amas sebagai pemilik sumber mata air untuk mengelolanya secara swadaya dan mengembangkan kepekaan masyarakat dalam bentuk negosiasi untuk membantu proses pengelolaan sumber mata air Desa Giri Mekar. Proses pengelolaan tersebut dilakukan untuk dimanfaatkan oleh masyarakat sekitar.

Sedangkan Desa Melatiwangi proses pengelolaan dikarenakan ada kejadian luar biasa, penduduk banyak yang terkena diare yang disebabkan mengkonsumsi sumber air kotor. Maka dari itu terdapat intervnsi dari Pemerintah Kabupaten bandung dengan membangun fasilitas untuk pengelolaan sumber air langsung dari Gunung Manglayang. Letak Melatiwangi yang dekat dengan Gunung Manglayang memudahkan bagi penduduk untuk memanfaatkan sumber air bersih, terutama didukung dengan fasilitas dari pemerintah.

c. Membangun hubungan untuk memperoleh dukungan dan legitimasi

Hubungan yang dibangun pertama-tama adalah hubungan antara Pa Amas sebagai pemilik sumber mata air dengan masyarakat sekitar untuk mengelola sendiri sumber mata airnya. Pa Amas sebagai pemilik inisiatif mengajak masyarakat sekitar untuk ikut membantu proses pengelolaan sumber mata air untuk selanjutnya disalurkan ke masyarakat.

Setelah hubungan ini terjalin dengan baik selanjutnya hubungan antara masyarakat sebagai pengelola dengan pihak desa. Hal ini dilakukan untuk memperlancar kegiatan karena tidak akan mungkin sebuah kegaitan dilakukan di sebuah desa tanpa memperoleh perizinan dari pihak desa sebagai pemerintah. Walaupun belum ada aturan yang baku namun setidaknya sudah ada pembicaraan secara non formal antara masyarakat dengan pihak desa tentang pengelolaan sumber mata air di Desa Giri Mekar.

Untuk Desa Melatiwangi hubungan terbentuk setelah adanya intervensi dari pemerintah. BUM Desa dibentuk untuk mengelola sumber air tersebut. Iuran diambil bagi warga yang memanfaatkan air untuk pemeliharaan fasilitas sumber mata air, seperti pipa, atau alat pompa.

Kemudian untuk melihat partisipasi yang terjadi pada tahapan pelibatan sumber daya ini bahwa dari dimensi Actors (aktor). terlhat bahwa aktor yang terlibat dalam proses sumber daya organisasi adalah masyarakat lokal yang memiliki kepedulian dalam pengelolaan air bersih. Desa Girimekar masyarakat lebih berperan besar dalam pegelolaan air bersih. Namun kondisinya cukup berbeda saat ini, sebab pada awal inisiatif pengelolaan air bersih terjadi dari masyarakat, ketika terbentuk kelompok 

Gunung Manglayang (Ramadhan Pancasilawan,dan Ahmad Buchari)

tersebut dna berjalan. Pemerintah melalui aparat desa berupaya ikut intervensi dalam kelompok tersebut, maka yang terjadi adalah kelompok yang sudah ada tidak berjalan. Bahkan sekarang dari beberapa sumber mata air hanya satu yang dikelola masyarakat dan diperuntukan oleh masyarakat, sedangkan beberapa sumber mata air lainnya sudah menjadi komersialisasi. Airnya dijual kepada penduduk yang membutuhkan air bersih untuk dikonsumsi.

Untuk di desa Melatiwangi, pengelolaan air bersih terjadi ketika terjadinya kejadian luar biasa, yaitu banyaknya masyarakat di Melatiwangi yang terkena diare yang disebabkan oleh sumber air yang tidak sehat, banyak masyarakat yang mengambil air dari sungai. Hal inilah yang menimbulkan inisiatif dari pemerintah untuk membangun instalasi air bersih yang berasal dari sumber mata air dari Gunung Manglayang. Bantuan ini dalam bentuk pipanisasi yang dipasang dari sumber air sampai ke tempat penduduk. Kemudian terbentuk Lembaga Pengelolaaan Air Bersih, yang saat rencananya tahun ini akan menjadi BUMdesa, yang berfungsi sebagai sumber pendapatan Desa.

Pada dimensi Knowledge (pengetahuan). Mengenai pengetahuan stakeholder yang terlibat dalam proses tahap peafaatan sumber daya ini, ini ternyata pengetahuan masyarakat terutama di Desa Melatiwangi tidak terlalu banyak memahami mengenai pemanfaatan sumber air, maka dari itu terjadi kejadian luar biasa yaitu terjangkitnya Diare massal karena masyarakatnya memanfaatkan air dari sungai yang tidak bersih. Maka dari itu dari sgi pengetahuan masyrakat Melatiwangi masih kurang paham mengenai pembentukan kelompok dalam pemanfaatan air bersih. Setelah adanya intervensi bantuan dana dari pemerintah kabupaten Bandung, baru adanya pembentukan kelompok yang melibatkan masyarakat untuk pengelolaan air bersih tersebut.

Kemudian untuk Desa Girimekar kondisi pemahaman masyarakat yang mengelola air bersih sudah baik sebab adanya kesadaran dari masyarakat yang menginginkan pemanfaatan air bersih dari sumber mata air yang dimiliki oelh warga tersebut. Pembentukan kelompok terjadi secra informal dengan pengelolaan air bersih berdasarkan partisipasi yang lingkupnya kecil. Sebab kelompok dibutuhkan untuk memelihara dalam pengelolaan air bersih seperti pipa saluran air, proses iuran, atau dalam upaya memperluas masyarakat yang memanfaatkan mata air tersebut.

\section{Tahap III (mengaktifkan sistem berorientasi pada tujuan setempat)}

a. Memungkinkan untuk membuat partisipasi dan keterlibatan masyarakat secara luas dengan adanya pengelolaan air, dan terbentuknya suatu lembaga masyarakat yang bersifat tidak formal walaupun hanya baru berisikan anggota dua orang. Hal itu bertujuan untuk memicu warga atau masyarakat lain untuk turut serta membantu kegiatan pengelolaan air di Desa Giri Mekar dan Desa Melatiwangi Kecamatan Cilengkrang Kabupaten Bandung. Kegiatan pengelolaan air tidak hanya di fokuskan pada satu titik wilayah tetapi nantinya pengelolaan tersebut akan melibatkan banyak masyarakat dan aparat desa. Karena kita mengetahui kebutuhan air sangat penting untuk kehidupan sehari-hari, untuk itu diperlukan kerja sama secara bersama-sama dan gotong royong untuk membangun pengelolaan air yang baik.

b. Menerima komunikasi aktif dan proses diskusidiskusi komunikasi yang dilakukan adalah oleh pihak pengelola yang diwakili oleh pihak $\mathrm{Pa}$ Amas dan oleh pihak Desa. Dari hasil wawacara yang dilakukan terlihat adanya hubungan dan komunikasi yang cukup intensif antara pihak pengelola dengan pihak desa. Komunikasi yang dilakukan bersifat tidak formal, komunikasi bisa berjalan baik bisa disebabkan salah satunya karena Pa Amas adalah Ketua Dusun di Desa Giri Mekar sehingga hubungan dan komunikasi sering dilakukan. Proses diskusi dengan masyarakat setempat pun dilakukan, mulai dari proses pembentukan kelembagaan yang terbentuk dari partisipasi masyarakat, hingga proses penyaluran air dari mata air ke warga sekitar. Karena hubungan antar masyaralat desa disini masih bersifat kekeluargaan maka komunikasi yang terjalin cukup sering. Dan juga karena mereka berada di satu kawasan yang sama sehingga semakin mempermudah hubungan dan proses komunikasi.

c. Memahami masalah dan mencari solusi dari pemahaman terhadap masyarakat terhadap pengelolaan air di Desa Giri Mekar dan Desa Melatiwangi Kecamatan Cilengkrang Kabupaten Bandung sudah cukup baik, dimulai dari kepekaan salah satu warga yang secara awam meneliti masalah yang ada pada system pengelolaan air yang dulunya dilakukan oleh pemerintah, pengelolaannya yang tidak merata dan tidak adil. Dari masalah tersebut muncul inisiatif untuk membuat kelembagaan sendiri yang berbasis masyarakat sekitar. Pengelolaan dilakukan oleh masyarakat untuk masyarakat. Sehingga sampai sekarang setelah pengelolaan tersebut berjalan dan dilakukan oleh masyarakat tidak ada keluhan lagi dari lingkungan tentang pengelolaan airnya.

\section{Tahap IV (pengoperasian sistem lokal)}

a. Bekerja di luar pengaturan sistem organisasi dalam komunitas eksternal bentuk pengelolaan air yang dilakukan oleh Pak Amas serta rekannya tidak beracuan pada organisasi yang bersifat formal. Maksudnya formal disini adalah adanya struktur organisasi, adanya visi dan misi, adanya targetan yang ingin di capai. Dan pengelolaannya tersebut tidak ada campur tangan dari pemerintah, melainkan inisiatif pribadi yang mendorong pak Amas untuk mengelola air. Pihak desa hanya mendukung dan menyetujui kegiatan yang 
dilakukan Pak Amas tanpa ada intervensi maupun turut campur dalam pengelolaannya.

b. Meyakinkan keterlibatan warga dan prestasi kelompok untuk membuat motivasi untuk perubahan Tidak mudah untuk melibatkan warga di dalam sebuah kegiatan. Diperlukan komunikasi yang efektif sehingga mendapat pengertian dan berhasil, Kesadaran yang didasarkan pada perhitungan dan pertimbangan, kesediaan melakukan sesuatu yang tumbuh dari dalam lubuk hati sendiri tanpa dipaksa orang lain, dan Adanya rasa tanggung jawab terhadap kepentingan bersama.

Berdasarkan dari penjelasan tersebut, bahwa paritisipasi masayrakat dalam kelembagaan pengelolaan air bersih di Kecamatan Cilengkrang, tidak semua desa yang memiliki mata air memiliki pola partisipasi yang sama, seperti di Desa Giri Mekar lebih dikelola secara sederhana dan masih sebatas dikelola oleh sedikit orang dan mata air dimiliki oleh individu yang sebagian ada yang sudah dikomersilkan da nada pula yang dikelola untuk kepentingan masyarakat.

Sedangkan di Desa Melatiwangi sudah dikelola oleh BUM Desa, hal ini dikarenakan didukung penuh oleh pemerintah kabupaten, maka dari itu BUM Desa kuat dan mampu mengelola mata air yang diambil langsung dari Manglayang.

Dalam pengelolaan sumber mata air tersebut menggunakan system pipanisasi air dan pemberian meteran ke setiap rumah. Dengan adanya pipanisasi dan pemberian meteran, penyaluran air bersih dapat dilakukan secara merata dan dapat diukur intensitas pemakaian air yang dilakukan oleh setiap rumah. Serta adanya bantuan dari pemerintah yang dilakukan secara berkala dalam pemberian selang dan pipa untuk menunjang kebutuhan pengelolaan air.

Secara keseluruhan model yang ada di daerah Manglayang mengenai pengelolaan air bersih cukup beragam. Hal ini dikarenakan penyebab pembentukan kelompok serta partisipasi masyarkaat yang berbedabeda. Jika melihat model di Desa Melatiwangi, kelompok terbentuk diprakarsai oleh pemerintah kabupaten dengan menggunakan modal yang cukup besar. Modal ini diperuntukan pembangunan instalasi untuk pemanfaatan air bersih yang diambil dari sumber mata air. Maka dari itu kelompok yang ada cukup kuat, sebab di desa ini menjadi perhatian utama pemerintah kabupaten. Sebab dengan terjadinya permasalahan kesehatan yang ditetapkan menjadi Kejadian Luar Biasa di desa ini menyebabkan pemerintah harus rela memberikan intervensi lebih bagi desa ini. Bentuknya adalah pembangunan fasilitas air bersih.

Sedangkan untuk desa Girimekar kelompok terbentuk dengan intensitas kecil dan tidak besar hingga banyak melibatkan masyarakat. Hal ini disebabkan sumber air bersih berada di lahan yang dimiliki oleh penduduk setempat. Maka dari itu ada kesadaran bahwa air bersih tersebut dikelola dan dimanfaatkan untuk masayrakat, namun masyarakat harus rela memberikan iuran untuk pemasangan fasilitas air bersih seperti pipa saluran air. Maka dari itu dengan me- manfaatkan social capital masayrakat yang seadanya menyebabkan kelompok disini tidak berkembang cepat, tetapi tingkat sustainabilitinya lebih baik, sebab kelompok terbentuk berdasarkan inisiatif dan kesukarelaan masyarakat untuk mengelola sumber air tersebut.

Jika melihat partisipasi yang terjadi pada tiap tahapan pembentukanmodel kelembagaan maka dari dimensi Actors (aktor). Berdasarkan hasil kajian terlhat bahwa actor yang terlibat dalam proses sumber daya organisasi adalah masyarakat lokal yang memiliki kepedulian dalam pengelolaan air bersih. Untuk di desa Melatiwangi, pengelolaan air bersih terjadi ketika terjadinya kejadian luar biasa, yaitu banyaknya masyarakat di Melatiwangi yang terkena diare yang disebabkan oleh sumber air yang tidak sehat, banyak masyarakat yang mengambil air dari sungai. Hal inilah yang menimbulkan inisiatif dari pemerintah untuk membangun instalasi air bersih yang berasal dari sumber mata air dari Gunung Manglayang. Bantuan ini dalam bentuk pipanisasi yang dipasanag dari sumber air sampai ke tempat penduduk. Maka dari itu jika melihat awal mulanya maka di Desa Melatiwangi actor yang terlibat lebih dominan dari pemerintah yang kemudian di kelola oleh masyarakat lokal.

Sedangkan untuk Desa Girimekar actor yang terlibat lebih banyak dari masyarakat lokal yang memiliki sumber air bersih dan juga masyarakat lokal ssetempat yang bahu-membahu dalam membangun pipa untuk menyalurkan air bersih ke rumah-rumah. Namun proses pipanisasi ini juga berdasarkan hasil kolektif dana yang di bebankan kepada pemilik rumah yang menginginkan air bersih dari sumber air ini.

PadadimensiKnowledge(pengetahuan). Mengenai pengetahuan stakeholder yang terlibat dalam proses kelembagaan ini ternyata pengetahuan masyarakat terutama di Desa Melatiwangi tidak terlalu banyak memahami mengenai pemanfaatan sumber air, maka dari itu terjadi kejadian luar biasa yaitu terjangkitnya Diare massal karena masyarakatnya memanfaatkan air dari sungai yang tidak bersih. Maka dari itu dari sgi pengetahuan masyrakat Melatiwangi masih kurang paham mengenai pembentukan kelompok dalam pemanfaatan air bersih. Setelah adanya intervensi bantuan dana dari pemerintah kabupaten Bandung, baru adanya pembentukan kelompok yang melibatkan masyarakat untuk pengelolaan air bersih tersebut.

Kemudian untuk Desa Girimekar kondisi pemahaman masyarakat yang mengelola air bersih sudah baik sebab adanya kesadaran dari masyarakat yang menginginkan pemanfaatan air bersih dari sumber mata air yang dimiliki oelh warga tersebut. Pembentukan kelompok terjadi secra informal dengan pengelolaan air bersih berdasarkan partisipasi yang lingkupnya kecil. Sebab kelompok dibutuhkan untuk memeli hara dalam pengelolaan air bersih seperti pipa saluran air, proses iuran, atau dalam upaya memperluas masyarakat yang memanfaatkan mata air tersebut. 
Studi Komparasi Model Kelembagaan Pengelolaan air Bersih Berbasis Partisipasi Masyarakat di Kawasan Kaki Gunung Manglayang (Ramadhan Pancasilawan,dan Ahmad Buchari)

Sedangkan kondisi situasi pada saat tahap pertama cukup berbeda, jika Girimekar lebih berdasarkan situasi informasl tanpa ada campur tangan dari pemerintah, masyarakat (terutama pemilik air) membuka bagi masyarakat untuk memanfaatkan sumber air yang ada dengan membayar iuran yang bertujuan untuk pemeliharaan dan pembelian instalasi air bersih. Sedangkan Melatiwangi kondisi awal situasinya le bih terjadi karena adanya pembentukan dari intervensi pemeirntah yang berupaya menangani permasalahan yang terjadi di desa tersebut. Kejadian Luar Biasa (KLB) penyakit Diare yang dialami warga Melatiwangi yang cukup banyak terjangkit, menyebabkan perlu adanya campur tangan pemerintah dalam pemanfaatan air bersih.

\section{SIMPULAN}

Model kelembagaan yang terbentuk di Manglayang cukup banyak dan relatif berbeda. Namun model yang lebih banyak adalah model kelembagaan yang terbentuk dengan lingkup kecil, namun pemanfaatan air bersih cukup luas. Hal ini lebih terjaga keberlanjutannya, namun kelembagaan yang ada tidak akan memiliki peluang untuk berkmbang besar.

Sedangkan model kelembagaan yang didukung intervensi pemerintah yang cukup besar, memiliki proses yang cukup cepat untuk terentuknya model kelembagaan dalam pengelolaan air bersih, bahkan dapat berkembang dan besar, namun hal ini harus terus didukung oleh pemerintah baik dari level desa sampai pemerintah kabupaten.

Berdasarkan kesimpulan di atas maka peneliti berusaha memberikan saran yang diharapkan dapat memberikan manfaat dan sumbangan pemiikiran dalam mengelola sumber mata air yang ada, ada pun saran - saran yang dapat peneliti berikan adalah sebagai berikut :

Pemerintah Kabupaten Bandung seharusya dapat memberikan pelayan terhadap masyarakatnya dalam memberikan air yang bersih, meskipun sumber mata air yang ada itu bukan milik pemerintah melainkan milik salah seorang masyarakat akan tetapi pemerintah dapat memberikan pelayanan berupa kerjasama dengan pemilik sumber mata air dalam pengelolaan air bersih tersebut dengan bekerjasama dalam membangun fasilitas dalam menyalurkan ar bersih

Pendampingan kelompok-kelompok yang sudah ada harus dilakukan terus terutama untuk mencegah terjaidnya privatisasi sumber air bersih atau adanya kelompok nakal yang memanfaatkan sumber air yang dilindungi untuk kebutuhan kelompok atau pribadi.

\section{DAFTAR PUSTAKA}

Bappenas (2003) Kebijakan Nasional Pembangunan Air Minum dan Penyehatan Lingkungan Berbasis Masyarakat, Bappenas - Departemen Permukiman dan Prasarana Wilayah - Departemen Kesehatan - Departemen Dalam Negeri Departemen Keuangan.

Creswell, J. W. 1994. Reseach Design : Qualitative \& Quantitative Approaches, Thousand Oaks London New Delhi, Sage Publications Inc.

Bernadinus Steni. 2004. Desentralisasi, Koordi nasi Dan Partisipasi Masyarakat Dalam Pengelolaan Sumberdaya Alam Pasca Otonomi Dae rah. Available at: http://www.huma.or.id (diakses tanggal 19 Agustus 2006).

Galvis, A. (2003) Technology selection for water treatment and pollution control. Universidad del Valle, Instituto Cinara Cali, Colombia, http:// www.irc.nl/page/104

Garna, Judistira K. 1999. Metoda Penelitian : Pendekatan Kualitatif, Bandung: Primaco Akademika c.v.

Moleong, Lexy. J. 1999. Metodologi Penelitian Kualitatif, Bandung : PT. Remaja Rosdakarya.

Ndraha, Taliziduhu. 1990. Pembangunan Masyarakat, mempersiapkan Masyarakat Tinggal Landas, Jakarta : Rineka.

Nurmandi, Achmad. 1999. Manajemen Perkotaan : Aktor, Organisasi dan Pengelolaan Daerah Perkotaan di Indonesia, Jogyakarta : Lingkaran Bangsa.

Parr J. dan R. Shaw (1991) Choosing an Appropriate Technology, WEDC Loughborough University Leicestershire LE11 3TU UK, http://www.lboro. ac.uk/departments/cv/wedc/

Suradinata, Ermaya. 1993. Kebijaksanaan Pembangunan dan Pelaksanaan Otonomi Daerah, Bandung.

Undang-Undang No. 7 tahun 2004 tentang Sumber Daya Air. 